\title{
Practical Integration: the Art of Balancing Values, Institutions and Knowledge. \\ Lessons from the History of British Public Health and Town Planning.
}

Forthcoming in Studies in History and Philosophy of Biological and Biomedical Sciences. Special issue - Interdisciplinary Integration: The real Grand Challenge for the life sciences?

Giovanni De Grandis

Norwegian University of Science and Technology

Department of Philosophy and Religious Studies,

NTNU Dragvoll,

7491 Trondheim, Norway

\begin{abstract}
The paper uses two historical examples, public health (1840-1880) and town planning (19451975 in Britain, to analyse the challenges faced by goal-driven research, an increasingly important trend in science policy, as exemplified by the prominence of calls for addressing Grand Challenges. Two key points are argued. (1) Given that the aim of research addressing social or global problems is to contribute to improving things, this research should include all the steps necessary to bring science and technology to fruition. This need is captured by the idea of practical integration, which brings this type of research under the umbrella of collective practical reason rather than under the aegis of science. Achieving practical integration is difficult for many reasons: the complexity of social needs, the plurality of values at stake, the limitation of our knowledge, the elusive nature of the skills needed to deal with uncertainty, incomplete information and asymmetries of power. Nevertheless, drawing from the lessons of the case studies, it is argued that (2) practical integration needs a proper balance between values, institutions and knowledge: i.e. a combination of mutual support and mutual limitation. Pursuing such a balance provides a flexible strategy for approximating practical integration.
\end{abstract}

Research for policy-making and practical action is inevitably conducted in a political context.

If research is to be 'useful' it must relate to the art of the possible

(Pahl 1975, p. 5)

the stakes here are not to make sciences 'progress', but to raise to the challenges facing society

(Stengers 2002, p. 98)

Grand Challenges are increasingly shaping research policy, its funding schemes and priorities. This is nowhere more apparent than in the biomedical and biological sciences, since 'society's need for the results of biological research has never been greater' (Losos et al, 2013, p. 1). The medical sciences have a long tradition of mediating between pursuing scientific understanding and putting it into practice, i.e. caring for the health of patients. Medicine has 
a dual image of an art and a science, and is indeed a discipline whose mission is as much to make patients' care grounded in sound scientific knowledge as to make clinical research conducive to better diagnoses, therapies and prevention. The biological sciences have surely not been without relations with practice, for instance in farming, husbandry, pharmacology and food production, but only in the last decades this practical vocation has taken a whole new dimension. ${ }^{1}$ The transformation is taking place at different levels: the life sciences themselves are being transformed by new approaches like integrative biology and systems biology; biotechnologies and bioindustry are attracting unprecedented investments and attention; the social and cultural impact of life sciences and biotechnologies are stimulating a growing amount of research in the humanities and the social sciences, so that that bioethics and biopolitics have become familiar concepts ${ }^{2}$.

The biological and biomedical sciences have thus a special interest in Grand Challenges: they are ideally positioned to produce research that has profound impact on urgent problems; but they are also facing risks, for promising impact without being able to deliver effective results can backfire quite seriously. It is therefore necessary to understand how to play the game, because what they are called to do is not just science. ${ }^{3}$ This paper attempts to provide some ideas and perspectives that can help: 1) researchers in understanding what to expect when participating in Grand Challenges and what to consider when planning their strategies; 2) scholars interested in some current transformations in the practice of science.

In the first section of this paper I argue that this trend calls for a broad concept of integration that, besides making possible collaboration across disciplines, enables knowledge to issue into viable action. This brings us into the domain of practical reason, hence the label practical integration. This idea stresses that engaging in research aimed at tackling the problems of society requires a methodological and epistemological shift from the focus on validity

\footnotetext{
${ }^{1}$ Some interesting examples of the relations between agriculture and biology are explored in a special issue on biology and agriculture published in 2006 in the Journal of the History of Biology. The papers highlight that the relation has by no means been one of linear application of biological discoveries to agricultural practices.

2 On the transformation of biology and its increasing social relevance see Palsson 2000; National Research Council 2009; Robinson et al 2010; Wake, 2008; Losos et al 2013; on the growing importance of biotechnologies and on the growth of biotech industry see Rifkin, 1999; Venter \& Cohen, 2004; Dyson, 2007; and Rasmussen, 2014.

${ }^{3}$ As a reviewer of the collection of essays A New Century of Biology cogently put it: 'a major challenge for biologists in the new century is to define an effective strategy for integrating the biological sciences with global economics and human social structure' (Bernardello, 2002, p. 235).
} 
characteristic of academic disciplines to an orientation towards relevance and effectiveness, towards what can work here and now in promoting well-being.

Achieving practical integration cannot be a matter of following a strict method or procedure: on the contrary it requires flexibility, imagination and ongoing learning. Thus I propose a heuristic perspective that is flexible, but sufficient to focus attention and efforts on the key factors of practical integration: values, institutions and knowledge. This perspective is illustrated through two case studies (two ante litteram Grand Challenges) that occupy sections 2 and 3 of the paper: Public Health in Victorian Britain, and Town Planning in post WWII Britain. These examples show how important it is to reach an ecological balance between values, institutions and knowledge: i.e. a dynamic balance through which each dimension both feeds and limits the others. They are also a good reminder - as I explain in the conclusion - of the need to be humble and realistic in our aims: rather than solving problems, our best hope is to build our ability to cope with them and to react and readjust to changing circumstances.

\section{Grand Challenges as collective practical reason}

\subsection{The coming of Grand Challenges}

Grand Challenges are becoming an increasingly fashionable concept in science policy (Lund Declaration, 2009; Jones, 2010; Calvert, 2013; Efstathiou, this issue). While the concept is vague and has been used in different ways (Brooks et al., 2009), its growing popularity is arguably due to its linking research priorities and important social goals (Jones, 2010; Calvert, 2013). Grand Challenges (henceforth GCs) are emerging as a banner to promote scientific research and technological innovation that contribute to tackle problems of great social relevance and to promote human well-being. GCs can thus be used as a broad blanket term to indicate all efforts to use and mobilise scientific and technological research to address serious challenges that are very relevant for society (cf. the notion of 'grand in scope challenges', Efstathiou, this issue). GCs are an upshot of 'the public's increasingly insistent demand that publicly funded research and education clearly show their connections to community needs' (Frodeman et al., 2001, s.p.): a demand that has fuelled the rise of mission-oriented science and transdisciplinarity. GCs are typically large and ambitious projects with time-horizon of more than one decade (cf. EPSRC, 2014, p. 4). Examples of issues that are the object of GCs 
are climate change, sustainable cities, clear water supply, antibiotic resistance (cf. IET, 2013)-all problems that require the contribution of the life sciences.

The aim of GCs calls is not just to describe and understand these issues: it is to deploy science and technology to make things better. ${ }^{4}$ Grand Challenges can therefore be seen as an interesting case of collective practical reason, for '[p]ractical reason aims at action that succeeds in furthering human wellbeing' (Kekes, 2010, p. 3). Responses to GCs can be described in the same way: aiming at promoting human well-being through successful action, where success is understood in terms of effectiveness, not in terms of efficacy. Thinking in terms of practical reason helps us in having clear that we are in a domain different from pure science with its methods and standards: we are instead in a domain akin to politics and its 'logic'.

By looking at GCs as collective practical reason we can see integration not only as an attempt to enable the knowledge and methods of different disciplines to work together, but also as the need to bring together knowledge and praxis. I call this integration of research and of collective action practical integration to distinguish it from the more familiar epistemic integration. ${ }^{6}$ While epistemic integration aims at making possible for different scientific disciplines, theories and methods to work together coherently, practical

\footnotetext{
${ }^{4}$ In order to be useful the concept of GCs need to be separated from an optimistic faith in technical solutions and silver bullets that, according to Brooks and colleagues (2009), often accompanies them. Nothing prevents from using the notion of GCs in association with a much more modest idiom that articulates the task in terms of problem-coping (cf. Funtowicz \& Ravetz, 1993, p. 99) and tackling challenges (cf. Brown et al., 2010).

${ }^{5}$ Daniel Sarewitz (1996, especially chaps. 8 and 9) has compellingly argued that dogmatic faith in scientific and technological solutions has become a surrogate for social action and misdirected social efforts. I agree with his analysis and I do not believe that GCs are in themselves a solution - they may even reinforce this trend. My hope is that if we can foster an understanding of GCs according to which their criteria of success need to be external to science, then we can escape the false and dangerous myths chastised by Sarewitz.

${ }^{6}$ I use the expression 'epistemic integration' to denote the prevailing concern of the literature on interdisciplinary integration: namely 'to overcome the conceptual and methodological boundaries between the prevailing fields of research' (Huutoniemi et al., 2010, p. 81). This kind of integration is at the core of influential understandings of interdisciplinarity. According to the often quoted report of the U.S. Committee on Facilitating Interdisciplinary Research for instance, 'Interdisciplinary research (IDR) is a mode of research by teams or individuals that integrates information, data, techniques, tools, perspectives, concepts, and/or theories from two or more disciplines or bodies of specialized knowledge' (National Research Council, 2004, p. 2). The centrality of the epistemic and cognitive dimension of integration is common in the literature on interdisciplinarity (see for instance Miller et al., 2008; Wagner et al., 2011; Green \& Wolkenhauer, 2012; Defila \& Di Giulio, 2015; Brister, this issue). While institutional and communicative aspects are often examined too (see for instance National Research Council, 2004, Chs. 4-5; Gerson, 2013; 0’Rourke \& Crowley, 2013), integration is primarily an epistemic/cognitive concept.
} 
integration aims at successful action in actual given circumstances. ${ }^{7}$ Practical integration includes all the information, evaluations, planning and implementation routines that turn techno-scientific knowledge first into actionable knowledge or usable technical artefacts, and then enable these latter to become part of workable interventions and established practices, from which in turn new knowledge is gained. Collective practical reason is thus wider than governance. In philosophy practical reason is traditionally seen as reasoning that issues in action. Accordingly, practical integration aims at targeting techno-scientific knowledge to the circumstances of action: i.e. to the constraints and affordances of contexts of action that are shaped by 'structured contingencies' (Rosenberg, 2006, p. 20).

\subsection{What is it that we try to bring together through the process of practical integration?}

In the context of GCs practical reason is constituted by techno-scientific expertise and instrumental rationality as well as by a combination of other intellectual skills, which in practice work in combination and are fundamentally interdependent, but for ease of exposition I analyse these separately. First there is local knowledge, which consists of acquaintance with the 'context of application' and the 'context of implications' respectively (Nowotny, Scott and Gibbons 2001). I call it knowledge although it seldom satisfies strict epistemic standards. The subject of local knowledge is the behaviour of local systems - including social, cultural, economic, natural and technical systems - and the interactions within and among them. Its sources are mainly firsthand experience and the need to operate within and across them. Social sciences and history can valuably contribute to this understanding, but they can never give the full picture. Equally valuable is the knowledge dispersed among stakeholders. Some of it is implicit, inarticulate and practical: it will only emerge ex post. Furthermore what is important and what is noise changes as circumstances evolve and according to our agenda. Local knowledge is always a transient synthesis drawn from a

\footnotetext{
${ }^{7}$ My distinction between epistemic and practical integration is similar to Jahn and colleagues' distinction between integration in interdisciplinarity and transdisciplinarity (Jahn et al., 2012, p. 2). However I see two advantages in making the distinction in terms of epistemic and practical integration. The first reason is to avoid that disagreement-which still exists-about the understanding of transdisciplinarity casts confusion on the nature of the distinction. The second reason is that the notion of practical integration makes much clearer how large and important is the gap between these two types of integration and that while epistemic integration is subsumed under practical integration its epistemic standards cannot apply to practical integration.
} 
large, incomplete, opaque and shifting repository of potential informationi.e. the actual life and environment of particular people and groups.

Second, there is what I call (loosely following Aristotle) 8 phronesis, by which I mean the ability to perceive values and to make wise value judgements. Here I use 'values' as a broad concept covering ideals, principles, goals, practices that matter to people and give meaning to their activities and choices.

Phronesis requires a set of skills: the breadth of imagination and sympathy that enable to see, understand and appreciate values that are not our own; the ability to weigh their relative importance. This latter includes both the ability to see what the perceived weight of a value is and the ability to influence and improve people's evaluations, i.e. to understand which evaluations can be changed and how. Finally it requires the wisdom to arrange things so as to make it possible to achieve, promote and honour as many values as possible. Typically in the context of GCs and collective action, we are concerned with the values and ethos of groups rather than individuals. Failure to understand them and to address and appease their concerns is going to breed conflict, hostility and mistrust and undermine the prospects of effective action.

Third there is what I call (following Detienne \& Vernant 1974, and Scott 1998) metis, which is the ability to make good judgements and decisions when confronting situations that are unique, fluid, uncertain and untypical. It is a combination of foresight, flexibility, resourcefulness and cunning. It requires apt cognitive frameworks (discrimination), a reliable moral compass (a sense of what is important), and timely decision making. We can thus see metis both as a specific skill and as a unifying moment in the working of practical reason. Metis can be described as 'the power of integrating or synthesising the fleeting, broken, infinitely various wisps and fragments that make up life at any level', and which leads to 'a sense of what will "work", and what will not' (Berlin, 1996, p. 47). It is the ability to read the circumstances and understand what they afford. In tackling a GC it is the ability to solve the conundrum produced by the previous forms of knowledge and skills:

- given the scientific knowledge and technological resources available,

- given the particular context in which we operate, with its resources, constraints, history and trends,

- given the values of the various stakeholders and the levers (incentives and disincentives) available to effect some shifts or changes,

\footnotetext{
${ }^{8}$ Aristotle discusses phronesis in book VI of the Nicomachean Ethics. It is a notoriously difficult book and interpretive controversies and disagreement abound. My use of phronesis does not claim to be an accurate interpretation of the Aristotelian concept.
} 
which strategy and which immediate moves are most likely to bring us closer to achieving our goal?

Different choices in researchers' life can provide a rough illustrations of the range of knowledge and skills that go into practical integration: writing a paper for a peer reviewed journal requires epistemic knowledge; deciding whether a different department or research unit will provide a better working environment requires local knowledge; deciding whether to accept the job offer from a university in a foreign country requires phronesis (balancing professional and family interests); leading a research group that achieves high reputation and attracts an ongoing stream of funding requires metis.

Compared to phronesis, metis operates where not only there are conflicting values and uncertainty, but there are unjust power relations, iniquitous motives, unreasonable positions and stubbornness as well. Smart responses to such circumstances are not necessarily ethical-Odysseus, the paragon of metis, is not a paragon of morality.

I have described phronesis and metis as personal qualities or virtues because it is easier to grasp them as personal characteristics. However, the practical integration needed for GCs is typically not a matter of integrating personal skills in one person or in a small group; it is more a question of smart organisational engineering. Practical integration is a matter of weaving together networks and of devising decision procedures as well as evaluating and learning mechanisms that will enact the collective and distributed version of practical reason. Ultimately what is important for the success of collective practical reason is to have a social-organisational process that embodies various types of knowledge, evaluative capacities and executive skills. Clearly this is a regulative ideal that we can only approximate, not least because it is indeterminate: we know that we want a process that leads to the most effective feasible action, but what this latter is cannot be determined or known. Nor can our goals and ideals be known in advance, '[s]ince learning aims to educate our preferences in the light of our possibilities, what we do and what we seek evolve together' (Pressman and Wildavsky, 1984, p. xvii; cf. Dewey, 1988, chs. 8 and 23). In aiming at actions that are effective and viable in the actual world, practical integration brings science and technology into a domain - untamed reality - that we cannot appraise and manipulate according to strict epistemic standards. With practical reason and practical integration we are operating in a domain of which there is no scientific knowledge-there is only scientific knowledge of some sub-domains under 
controlled circumstances, not of the whole domain in its actual circumstances (cf. Sarewitz, 2010).

So what can be achieved in uncontrolled reality is beyond our knowledge and practical integration is an indeterminate ideal. This might sound disappointing, but it should not. If we do not make any ungrounded metaphysical assumption about the nature of the world and our ability to fully and systematically understand it, we must accept that in trying to improve our lot we are tinkering with a reality that escapes our full understanding (cf. Dupré, 1996, p. 117) and with possibilities not yet disclosed. This is a healthy and constructive form of scepticism, one that urges us to get rid of the delusions that prevent us from acknowledging the real magnitude of the challenges we face, and that invites us to look for modest and pragmatic approaches. Finally, it reminds us that the epistemic credentials of goal-driven research projects are not those of their contributing scientific disciplines, but those of their implementation machinery, i.e. those of governance, administration and marketing.

\subsection{How can we approximate practical integration?}

There are further reasons why practical integration is an elusive ideal: a) its highly contextual nature, b) the open and plural nature of phronesis, and c) the very nature of metis - which begins precisely where general and formalised knowledge and rationality end. Context-responsiveness, imagination and judgements are difficult to achieve following standardised procedures and methods. Therefore the approach to practical integration that I propose is simply a heuristic perspective focused on the interactions between Values, Institutions and Knowledge, henceforth VIK perspective (see figure 1).

Figure 1: The VIK perspective (or VIK triangle)

\section{Values}

Institutions

Knowledge

The VIK perspective can be used for analysing and interpreting cases of practical integration or of failures to achieve it - as I do in my case studies. 
But it is also offered as a practical and prudential compass that points the attention to three dimensions that are crucial in the successful exercise of practical reason. Its practical value is based on the hypothesis that successful social action depends on a working balance between the power of Values, Institutions and Knowledge: on their feeding and limiting each other so that an ecological balance is maintained.

Values, knowledge and institutions are broad categories: so let me explain how I use them. Under values I include all goals, aspirations and ideals that are endorsed and/or acted upon by some actors. They are perceived values, not necessarily justified values. In my discussion and case studies mostly ideals, goals and interests are grouped under the label of values. One last remark is very important: the category of values denotes a set that is populated by many tokens that are neither consistent nor necessarily compatible, so it is assumed that conflicts of values are ubiquitous: they are the norm, but they are troublesome nonetheless. I use the term knowledge to indicate not only these articulate, systematic, academic forms of knowledge, but I also include local and implicit knowledge, skills and know-how. Under institutions I include both what sociologists call institutions and what they call organizations, so both the economic market and a particular firm are institutions, both religion and a specific parish. Branches of the public administration and NGOs, clubs and societies, well established traditions and cultural conventions are all included.

Now we can better see why the VIK triangle is a usefully simple and flexible tool: by focusing on its three components we are forced to make use and combine the knowledges and capacities illustrated in the previous section. The plurality of values urges us to make them explicit, understand their sphere(s) of pertinence and weigh them against each other in specific contexts. Looking at existing institutions forces us to acquire local knowledge and reveals implicit and taken for granted values. Designing or adapting organizations for implementing our plans engages our imagination and metis. Knowledge points our attention to the need for acquiring reliable and relevant scientific and local knowledge. Finally, instrumental reasoning and deliberation about ends need to work together. Trying to balance the three dimensions of the VIK triangle is thus an indirect strategy for achieving practical integration; a strategy that can inspire both the architecture of the network involved in a GC and the actions of individuals within the network. For instance it can inspire the construction of more inclusive networks, more 
open communication channels, and make individuals more aware of systemic interdependencies.

\subsection{What is distinctive about Practical Integration and the VIK framework?}

The notion of practical integration presents some similarities and affinities with existing ideas, approaches, methods. Readers will have noticed affinities with post-normal science (Functowicz \& Ravetz, 1993), with Mode 2 knowledge production (Gibbons et al., 1994; Nowotny et al., 2001 and 2003), with action research (Argyris et al., 1985), with some understandings of transdisciplinarity (Bammer, 2012; Brown et al., 2010; Hirsh Hadorn et al., 2010; Mitchell et al., 2015), with philosophical pragmatism (Dewey, 2004; Kitcher, 2012; Rorty, 1999), with positions that are critical towards scientistic and reductionistic understandings of rationality and method (Toulmin, 2001; Flyvbjerg, 1993 and 2001; Scott, 1998). The concept closer to practical integration is that of 'translational integration' proposed by Sabina Leonelli (2013, see in particular pp. $510-2) .{ }^{9}$ However, I want to point out what is distinctive about the approach I advocate and why I introduce new labels.

As anticipated in footnote 2, the concept of practical integration stresses that integration for goal-driven research occupies a logical space very different from that of epistemic integration typical of 'academic' research. While this latter is governed by epistemological criteria of validity - e.g. surviving experimental testing or critical peer scrutiny - practical integration is governed by pragmatic criteria of incremental improvement: a solution has to be viable, reasonably expected to produce more good than harm, costeffective, reversible and improvable, promoting the creation of capabilities and of ongoing learning (cf. Scott, 1998, ch. 10; Stirling, 2010; Mitchell et al., 2015). These criteria are hard to reduce to formalized methods and clearly imbued with a variety of social values. Compared to post-normal science, Mode 2 knowledge production, and Swiss-German style transdisciplinarity ${ }^{10}$, practical integration brings together science and political action but not under the idea of science. Instead it stresses that it is science that, so to speak, is a guest in the house of collective decisions, not politics which is granted

\footnotetext{
${ }^{9}$ I am indebted to O'Rourke, Crowley and Gonnerman (this issue, fn 22) for calling my attention to Leonelli's paper. She applies her concept of translational integration to a much narrower domain (plant science) and she does not develop it in great details, nevertheless the affinity with practical integration is such that the example she uses - the recruitement of scientists and stakeholders in the attempt to tackle the infestation of Phytophtora ramorum in the UK-can be used as effectively as an example of practical integration.

10 See Klein (2010, p. 25).
} 
citizenship into science. Practical integration is thus immune from two common criticisms addressed to theorists of transdisciplinarity: 1) of generating an 'anomalous' idea of science that confusingly merges 'strict science and political action' (Alvargonzález, 2011, p. 400); 2) of reclaiming the prestige of science for enterprises in which sciences provide inputs, but cannot validate the outcomes (cf. Alvargonzález, 2011, pp. 398-9; Dupré, 1996, p. 116) - e.g. when the plurality of scientific perspectives is reduced to a single view to simplify decision making (Stirling, 2010).

In my use, collective practical reason is a hybrid as compared to the traditional categories of science and politics, and even in relation to the less pure categories of, say, applied science, administrative and implementation studies, or applied ethics. It is not an attempt to bring science and technology under the authority of ethics or democratic politics. It is rather an attempt to acknowledge that reasoning about ends cannot be disentangled from talking about means, and that talking about means sensibly requires engaging the expertise coming both from technoscience and from administration and management-including communication and marketing. Engaging expertise has to be taken literally: expertise is not to be taken at face value, but has to put itself on the line, expose itself to new challenges and new learning. So compared to pure science and to ethical or political theory, collective practical reason is about achieving goals in given circumstances and determining goals in light of the required and available means - and this means facing some ugly choices and even dealing with evil. It demands both from sciences and from ethics that in their practical use they take account of political realism and practical necessities, but it does not aim at limiting sciences and ethics to their practical uses: we need both the 'pure' and the streetwise versions of them ${ }^{11}$.

Practical integration can be usefully compared to two works with which it has many common features and goals. Tackling Wicked Problems through the Transdisciplinary Imagination (Brown et al., 2010) aims at providing tools and inspiration to researchers engaged in transdisciplinary goal-driven projects. It thus shares with practical integration the concern for helping in having an impact and making a difference. Furthermore, the emphasis on the importance of the imagination provides another strong affinity. Not only imagination is a key element of both phronesis and metis, but it also highlights

\footnotetext{
${ }^{11}$ I do not mean to suggest that 'pure' science is independent from external influences. There is a large literature on the relation between science and politics and between knowledge and power, but this topic is beyond the scope of the present analysis.
} 
the value of ways of thinking and doing typical of the arts and humanities. Finally this work emphasizes the importance of using a variety of methods and approaches: a pluralistic stance shared by practical integration. ${ }^{12}$ Yet, in spite of these important commonalities, Tackling Wicked Problems often remains hooked to the prevailing epistemological understanding of integration. For instance in the introduction the authors first stress that wicked problems require changes in society, as well as different and more imaginative decision making, but then in describing diversity they fall back to a purely epistemological account of it. Transdisciplinarity is described as the 'collective understanding of an issue', which includes 'all validated constructions of knowledge and their worldviews and methods of inquiry' ( $p$. 4). The problem facing the increasingly close collaboration between researchers and decision-makers is thus described as that of 'bringing together people with radically different understandings of the world' (p. 5, emphasis mine) - rather than mentioning differences in interests, values, power, voice. This reduction of the issue of pluralism and diversity to a basically epistemological problem - apparent also in chapter 4, where five different knowledge cultures that need to be brought together are identifieddoes not reflect the spirit of the book, rather it reveals that the discourse on integration has been captured by the epistemological idiom (on capture see Brister, this issue). The concept of practical integration could have enabled them to provide a fuller account of what needs to be integrated besides knowledge (i.e. values and institutions, which are often discussed in the book) and of the capabilities needed for such broader integration (e.g. phronesis, metis).

The second example comes from comparing practical integration with the idea of 'Integration and Implementation Sciences' (I2S) proposed by Gabriele Bammer (2012). The affinities are several and important: the focus on realworld problem, the ambition to help policy makers and promote changes in practice, the emphasis on the importance of stakeholders' and practitioners' knowledge, the attention to implementation, the impossibility of avoiding unknowns and the necessary imperfection of every solution. The main difference is that practical integration expresses a sceptical stance towards Bammer's hope to establish a quite structured new discipline under the label of Integration and Implementation Sciences, and especially towards the belief that this requires a "'Big Science" -type project' (Bammer, 2012, p. 6). A

\footnotetext{
12 Practical integration does not share the holistic stance though: pluralism brings with it a diversity that should not be ignored (here I follow Dupré, 1996; Stirling, 2010; Sarewitz, 2010, as well as the tradition of ethical pluralism inspired by Isaiah Berlin).
} 
network favouring communication and exchange of ideas among practical projects is surely extremely useful, but the idea that this could be driven by a top-down Big Science project seems both unrealistic and ill-suited to accommodate the importance of the local and the pattern of development of digital networks. Public intervention and funding should encourage and support the development of the infrastructure, tools and capabilities, but the process should be demand-driven, bottom-up. Finally, because of the indeterminate, imagination- and judgment-based nature of practical integration, I would describe integration and implementation as arts rather than as sciences. To summarize, practical integration can fit with Bammer's concept of 'integrative applied research' (Bammer, 2012, p. 18), but remains sceptical on the more ambitious idea of Integration and Implementation Sciences, especially if conceived as Big Science.

Let me wrap up the key points. Practical integration does not claim to discover something new, but to give a name to an aspiration implicit in some of the literature on transdisciplinarity. As Roderick Lawrence points out, 'there clearly is a growing number of authors who challenge interpretations of transdisciplinary research that do not address broader social and political dimensions that ought to be integrated in the research agenda' (Lawrence, 2015, p. 8). Practical integration is not hostile towards epistemic integration: it simply encompasses this latter within a broader integrative task, which is both epistemically fuzzier and of a higher order. The polemical intention is not against the importance of epistemic integration, but against the hegemony of the epistemological idiom when thinking about integration. This hegemony is harmful for several reasons:

- it makes it hard to acknowledge the role of idiographic and quasiaesthetic concepts in practical integration;

- it makes epistemic robustness rather than relevance to human wellbeing the focus of goal-directed research-thus failing to appreciate the difference between fundamental research and practical research;

- it encourages the inflation of science-watering down its specificityand a rhetorical use of the words 'science' and 'scientific'.

The concept of practical integration tries to avoid these mistakes, while the VIK perspective offers an easy-to-grasp and flexible guide to practical integration.

In the following two sections I discuss two case studies - two ante litteram examples of Grand Challenges - that show the heuristic value of the VIK perspective and provide evidence in support of the hypothesis that an 
ecologic balance between Values, Institutions and Knowledge is needed. They are examples of both individual and collective practical reason at work, although it does not always work as it should. The notions of local knowledge, phronesis and metis help in understanding what worked and what did not.

\section{Public Health in early Victorian Britain}

The transformations triggered by the combination of demographic growth and mass urbanization in $19^{\text {th }}$ Century Britain generated extremely unhealthy living conditions in large parts of the cities (cf. MacDonagh, 1977, pp. 133-5; Wohl, 1983: chs. 1-5). Tackling those unsanitary conditions was an obvious case of ante litteram Grand Challenge.

The problem was huge, from the 1830s awareness kept growing and a highly motivated group of sanitary campaigners tried to stir public authorities into action. This lobbying effort is an early example of integrating crossdisciplinary knowledge and ethical motives. Table 1 below summarizes some key features of the circumstances in which sanitary campaigners operated ${ }^{13}$.

${ }^{13}$ Cf. MacDonagh (1977, ch. 1). 


\begin{tabular}{|c|c|}
\hline $\begin{array}{c}\text { Circumstances hindering public } \\
\text { intervention }\end{array}$ & \begin{tabular}{|c|}
$\begin{array}{c}\text { Circumstances favouring public } \\
\text { intervention }\end{array}$ \\
\end{tabular} \\
\hline \multicolumn{2}{|c|}{ Values and beliefs } \\
\hline $\begin{array}{l}\text { Powerful and politically well represented vested } \\
\text { interests of those who stood to lose by the } \\
\text { introduction of public health measures (e.g. } \\
\text { slum-lords, water companies, noxious trades and } \\
\text { industries etc.). } \\
\text { Doctrine of 'philosophical necessity'-humans } \\
\text { should not interfere with the natural course of } \\
\text { things. }\end{array}$ & $\begin{array}{l}\text { Humanitarian and socially reformist zeal } \\
\text { exemplified by Evangelicalism and } \\
\text { Utilitarianism. } \\
\text { Momentous economic and demographic } \\
\text { transformations called for governmental } \\
\text { action and new responsibilities. } \\
\text { Growth of interest in social statistics. }\end{array}$ \\
\hline Doctrine of laissez-faire in economics. & $\begin{array}{l}\text { Fear of social turmoil (especially around } \\
\text { 1848). }\end{array}$ \\
\hline Aversion towards increased taxation. & Fear of epidemics (especially cholera). \\
\hline $\begin{array}{l}\text { Sanctity of home and family_-more generally } \\
\text { defence of traditional English liberties_- } \\
\text { individualism. }\end{array}$ & Fear of degeneration (physical and moral). \\
\hline $\begin{array}{l}\text { Fear of creating dependence and of undermining } \\
\text { rational prudence. }\end{array}$ & $\begin{array}{l}\text { Growing belief in a connection between } \\
\text { cleanliness and morality. }\end{array}$ \\
\hline \multicolumn{2}{|c|}{ Institutions and politics } \\
\hline $\begin{array}{l}\text { At the beginning of the Victorian age, } \\
\text { government had very limited tasks, } \\
\text { responsibilities and resources (both human and } \\
\text { financial). }\end{array}$ & $\begin{array}{l}\text { The } 1832 \text { reform bill gave more power to } \\
\text { the emerging urban bourgeois and middle } \\
\text { classes. }\end{array}$ \\
\hline $\begin{array}{l}\text { Very small—yet growing—administrative } \\
\text { structure and expertise. }\end{array}$ & $\begin{array}{l}\text { Growth of knowledge-informed } \\
\text { government: Parliamentary and Royal } \\
\text { commissions and inquiries. }\end{array}$ \\
\hline $\begin{array}{l}\text { Strong resistance against administrative } \\
\text { rationalization and centralization. }\end{array}$ & Growth of local activism and civic pride. \\
\hline $\begin{array}{l}\text { Extremely fragmented and un-coordinated } \\
\text { nature of local bodies }\end{array}$ & \\
\hline \multicolumn{2}{|c|}{$\begin{array}{l}\text { Knowledge and science } \\
\end{array}$} \\
\hline $\begin{array}{l}\text { Limited medical knowledge-medicine had still } \\
\text { very limited diagnostic and therapeutic } \\
\text { power-and poor social status of medicine }\end{array}$ & $\begin{array}{l}\text { The miasmatic theory of disease provided a } \\
\text { basis for promoting hygiene. } \\
\text { Slow emergence of scientific medicine (lab- } \\
\text { based) and of a more reputable medical } \\
\text { profession. } \\
\text { Advances in civil engineering (e.g. improved } \\
\text { sewers, WC toilets etc.). }\end{array}$ \\
\hline
\end{tabular}


In order to succeed in stimulating effective action for the promotion of public health, its promoters needed to weave together the values, knowledge and institutions that could provide support for it and find a way to appease some of those pitched against them. How was this done? How successfully? The traditional account of the history of public health tells a success story: although it took several decades, had to overcome many challenges and temporary setbacks, eventually by the end of the Victorian age the aims of the sanitary reformers had been achieved and public health had established itself as an important branch of public administration, a respected profession and academic discipline. The stories of three key figures in early Victorian public health provide a telling illustration of the importance of taking into considerations values, institutions and knowledge and of balancing them. Here we are going to follow three important figures:

- Edwin Chadwick a Benthamite lawyer of formidable energy and a key figure in British public administration,

- John Simon a brilliant pathologist who became the first Medical Officer of Health for the city of London and later the leading figure in public health at national level,

- William Farr a physician who became the driving force of the newly established General Registrar Office and one of the most respected statisticians of his time.

The first story exemplifies an initial remarkable success followed by an equally noteworthy setback, while the latter two show how through metis and the ability to integrate values, institutions and knowledge, balancing their demands and seizing opportunities lasting progress was achieved.

\subsection{Edwin Chadwick: success and failure}

Chadwick led the first sustained attempt to realize a bold public health programme in Britain. The attempt succeeded in bringing public health into the public awareness and policy agenda. Chadwick can be credited for some important legislative and institutional achievements - most notably the Public Health Act 1848 and the establishment of the General Board of Health. But ultimately Chadwick failed, was forced to resign (in 1854), and his programme was superseded by a new and different approach to public health (that of John Simon described below). It has become a commonplace to blame Chadwick's authoritarian, dogmatic and inflexible character for the failure of his programme. There is a good deal of truth in this explanation; however we can gain further insights by looking at how he handled values, institutions and knowledge. Chadwick had a powerful intuition when he realized that 
moral outrage at appalling urban living conditions and excess mortality could be supported by an economic argument showing that removing environmental causes of disease would have prevented much poverty and saved taxpayers money. The sanitarian programme of cleaning cities and removing filth could thus satisfy humanitarian feelings and taxpayers' interests, without interfering with the labour market and incentives to work. This was a powerful and effective way of deploying a plurality of intensely felt values in support of public health interventions - a remarkable success in achieving integration within the domain of values.

On the side of knowledge, the miasmatic theory of disease supported Chadwick's environmental approach to health. More importantly and originally, he understood the potential of social statistics (mortality data) in backing his case, and of civil engineering (improved sewers design) in providing technical solutions. Nevertheless there were some weaknesses: his use of statistics and of evidence was rigged and far from impartial. The most alert critics like the young statistician F.G.P. Neison compellingly exposed the flaws (Cullen, 1975, p. 60; Hamlin, 1996). While this was not a serious blow to his case, in the long run his closed and instrumental attitude to knowledge would have also come to a head. Chadwick was interested in knowledge and science only as long as they were expedient for the achievement of his own goals and plans: once he had found some backing he showed no interest in promoting further knowledge or in learning lessons from rapidly developing sciences. His stubborn opposition to germ theory is a good case in point.

While Chadwick's attitude to knowledge was flawed and could not be sustained in the long run, it was his badly misjudged attitude in handling some key institutions that caused his failure. His implementation strategy was rational and consistent in theory, but misapprehended what was possible in the administrative and cultural environment in which he was operating. His vision of 'strong executive bodies, appointed rather than elected and furnished with authority and money from central government to undertake the massive task of sanitary reform' (Halliday, 2011, p. 131) rubbed against too many interests and sensibilities. He 'misjudged the ferocity of opposition to his hope to centralize control of public health policy and activity' (Bynum, 1994, p. 78). Vested interests and local authorities could not stomach the prospect of such dictatorial powers above them, and public opinion equally dreaded the breach of traditional British liberties and of the sanctity of home and private property. He became the object of widespread hatred and of violent attacks in the press, as shown by two striking quotations from The 
Times: 'We prefer to take our chances with Cholera and the rest than be bullied into health' (quoted in Rosen, 1993, p. 200); 'The truth is, we do not like paternal governments ... This is another reason why the CHADWICKIAN sanitary regime so signally failed' (quoted in Bynum, 1994, p. 78). The other great strategic error was Chadwick's inability to win the support of the professional category that had more to gain from the consolidation of public health: the medical profession. His determination to look only for administrative and engineering solutions precluded the possibility of winning the support of doctors (Novak, 1973, Lambert, 1963, pp. 62-3). In the end his attempt to achieve his goals through imposing his views against strenuous opposition costed him his career:

At the early age of 54 , he was forced to give up an active career in public administration, and while he was able to see the realization of many of his ideas in the course of his life, he took no active part in their development (Rosen, 1993, p. 200).

In sum, Chadwick had a great insight on how to bring apparently conflicting values to support public health; he was also shrewd in the use of knowledge and in turning it into a rhetorical weapon and must be credited for having a prescient vision of the importance of having efficient administrative organizations. But he failed to give proper weight to knowledge (especially local) with the result of overlooking some values and staking all its chances on an administrative design that could not be accepted by existing institutions and feelings. He was able to see which means would have been necessary to achieve his goals, but unable to adapt his ends to the means actually available. He was incapable to feedback inputs into his comprehensive but doctrinaire project, to see the difference between theoretical plans and practical strategies developed within existing constraints and affordances. Looking only at the aspects of reality that supported and confirmed his vision, Chadwick blinded himself to the chance of learning from the struggles of the implementation process.

As a perceptive contemporary put it, the Board of Health [under Chadwick] 'was steadily guided by the assumption that all needful sanitary knowledge had been conclusively attained and administrative action followed as a matter of course'. Hence its self-confident impetuosity, its 'scientific onesidedness', and its failure 'to distinguish between opinion and knowledge' (Lambert, 1963, p. 266; cf. Wohl, 1983, p. 153). 
Chadwick egregiously failed to integrate fundamental local knowledge and practical experience in his vision. His system lacked the feedback channels that could have enabled his plan to be constantly updated through new scientific knowledge and politico-administrative experience. There was no balance in the VIK triangle, there was no practical learning.

\subsection{Farr and Simon: two success stories}

William Farr and John Simon managed to achieve greater and longer lasting results and the VIK perspective helps us in understanding why they performed better than Chadwick. Farr's main achievement was to lead (from 1839 to 1880) the freshly created General Registrar Office (henceforth GRO) to become an agency capable of succeeding in two important tasks:

1. supplying the sanitary movement with the statistics they needed to support their case and stir authorities into action; and

2. contributing valuably to the progress of statistical techniques and supplying data of high scientific value.

From the VIK perspective the GRO under Farr's guidance was inspired by the powerful combination of humanitarian and economic values already at work in Chadwick, but rather than subordinating knowledge to its practical goals, it managed to advance both. Regarding institutions, it was able to adapt to circumstances: to stimulate the creation of the needed administrative structures, but also to exploit the opportunities that the current situation afforded. Furthermore feedback channels enabled practical learning. A key feature in the GRO's success in practical integration was what Simon Szreter has called his 'twin pronged publication strategy to maximize both its political and scientific impact' (Szreter, 2005, p. 242; cf. Cullen, 1975, pp. 40-1). The practical impact was achieved through the constant and timely production of Weekly and Quarterly Reports and Annual Summaries. These publications had to be timely in order to monitor changes in population health and implement remedial actions. They were aimed both at local authorities and doctors and at the public opinion - so that it could stir authorities into action. The information provided in these reports thus needed to be clear and easy to use.

The scientific impact instead was achieved through the publication of the Annual Reports - not to be confused with the Annual Summaries - that provided much more extensive and rigorous analysis but were published with a delay of up to 4 years. Even more scientifically thorough and ambitious were the monumental decennial Supplements associated with the 
national census. These documents were aimed at a specialist audience and were scientifically much more rigorous and thorough. (Eyler, 1979, pp. 141-2; Szreter, 2005, pp. 245-6).

If we look at the evolution of the communication strategy we can appreciate that Farr and the GRO were responsive to the changing character of their audience. At first, Farr's strategy was primarily aimed at "'converting" an illinformed general public' (Szreter, 2005, p. 262). But in time things changed: an expert and organized professional group of public health practitioners slowly grew, and later bacteriology emerged and discredited the miasmatic theory. As a result the most effective audience to target was now a much more professional and scientifically minded one; furthermore statistics were no longer the key instrument of prevention: new standards of precision and specificity were now demanded. As a consequence the GRO reoriented its dissemination strategy towards the production of more accurate and more specific statistics, so that in the decades after Farr, the shift from a predominantly popularizing to predominantly scientific style was completed (Szreter, 2005, pp. 261-3).

Farr understood that local authorities would have resisted an invasive role of central government and would have not waived their traditional prerogatives. Accordingly he accepted the idea that public health would be entrusted to local authorities. Soon he managed to put a local value-local pride - in the service of the cause of public health. He decided to publish comparative tables of mortality - with the intention of pushing into action the towns with the higher mortality rates - a clever way of playing with local shame and pride. Then he realized that his objective would have been served even better by publishing the mortality rates in the form of competitive league tables. Later, he understood that the most effective ideal and benchmark of achievable health results was the notion of Healthy Districts, i.e. he used the districts with the lowest mortality rates as benchmarks of what was achievable and for calculating how many lives could be saved. This was an 'ingenious rhetorical invention' (Szreter, 2005, p. 247) but also an extremely useful scientific model. It had three great merits: 1 ) it could be presented as a concrete and achievable standard - since it was actually achieved by the better faring districts - not an abstract model proposing a hypothetical target, therefore it was hard to dismiss for local authorities; 2) it was a dynamic and self-adjusting model that would have kept raising the bar as health conditions improved; 3 ) it enabled the calculation of the avoidable mortality for each district, thus providing a very vivid illustration of what 
was at stake and what was the price of inaction. This example of metis shows graphically how attention to institutions, values and knowledge could enable setting realistic ends and choosing effective means.

The GRO also offers an interesting example of how practical goals determined by considerations of value and by administrative capabilities were incorporated into knowledge production. The example comes from two classification systems used by the GRO in collecting and organizing data. Both the taxonomy of causes of death and that of occupations were shaped by the practical need of avoiding preventable deaths. As Szreter notices, 'the concept of preventability ... entails implied claims, regarding first the presumed efficacy of available remedial measures, and, second, the existence of a responsible executive agency, willing to undertake such preventive measures' (Szreter, 2005, p. 257). So we see both practical goals and organizations' capacities affecting knowledge production: what kinds of data and statistics were interesting and useful was partly determined by a) what was considered politically and administratively feasible, and b) the available preventive measures backed by the medical knowledge of the time (see Szreter, 2005 and Eyler, 1979, pp. 52-60 for a discussion of Farr's nosology and its evolution).

The pursuit of practical impact introduces elements of contingency into knowledge. The occupational taxonomy shows this clearly: Higgs (1991) argues that the criteria used for the GRO's occupational statistics make them suitable only for the purpose of public health and criticizes colleagues who have used them in economic history ${ }^{14}$. The attempt to balance the claims of practical goals, epistemic standards and institutional feasibility implies some trade-offs and we need to be aware of the need to consider which assumptions and criteria have been incorporated in the knowledge we use. Practical knowledge that has grip on reality is not fit for all theoretical or practical purposes.

An even more striking example of metis in achieving practical integration is offered by the career of John Simon. He should be credited for at least two major achievements in the process of consolidation of English public health:

\footnotetext{
14 Occupational groups were constructed around the kind of material things (or lack thereof) they were working with and the environment where they were working. For instance 'clerks in law practices were placed amongst the professions but clerks in iron works were placed in the industrial orders under iron manufacture' (Higgs 1991, p. 474).
} 
1. as Medical Officer of Health (henceforth $\mathrm{MOH}$ ) for the City of London in the years 1848-55 he was such an inspirational example that he contributed decisively to defining the role of the $\mathrm{MOH}$ as a central figure of public health at local level;

2. through his vision, scientific reputation and administrative talent during his years (1855-71) at the Privy Council he managed to edify an efficient national system of public health staffed by increasingly professionalized personnel, supported by - and supporting - steadily growing medical knowledge.

These achievements depended largely on his ability to integrate and balance values, knowledge and institutions. In particular he succeeded in setting in motion cycles of growth in which administrative expansion and knowledge production fed each other. He used existing administrative structures and powers to collect the evidence needed to advocate necessary reforms. But through this very process, and the meticulous preventive activity, his administrative agencies built the capabilities and experience that endowed them with the know-how required to carry out new tasks and expanded responsibilities.

Simon was adaptable to circumstances and able to understand which advances were possible at each stage and which available steps would have contributed to the eventual overcoming of the present strictures. He thus developed a modus operandi that can be described as pragmatic incrementalism with a vision - an ambitious and evolving vision. As Lambert explains, he had

A conception of sanitary administration not as the passive application of fixed knowledge and rigid formulae, but rather as itself a perpetual experiment, continually discovering, rejecting defining and revising knowledge and methods of execution in the effort to attain the paramount end: the extinction of all preventable disease (Lambert, 1963, p. 168).

Unlike Chadwick, he understood that prevailing opinion, dominating interests and deeply rooted conventions and traditions could not be confronted head-on, that often one had to make the most of unfavourable circumstances or bad deals and work patiently in order to be prepared to seize the opportunity when circumstances would change and turn more auspicious. He explained that his experience working for local authorities 'had taught me lessons I could not otherwise have learnt, as to factors which in this country are essential to social progress' (quoted in Lambert, 1963, p. 237). These included respect for long established institutions and for the 
opinion and feelings of the people and its representatives: there was no use in running ahead; a gradual process of education was the only way of achieving success. To this educational work Simon contributed with remarkable success through his skilful reports: documents so successful in blending authoritative expertise, tireless exposure of evils and eloquent exhortations, that they were routinely published by the most influential newspapers.

Simon was particularly successful in using inquiries to expose the real nature and scale of unsanitary living conditions as well as the limits of current knowledge. Inquiries brought to the light enough knowledge to make a case for prompt action, but at the same time stressed the need to have more and better knowledge. Awareness of limits fuelled efforts to overcome these limits. This grounded a balanced, dynamic and expansive model of integration in which the three dimensions reinforced each other. To be sure, successful and inspiring as this model looks, it was not immune from some questionable features. For instance, one may wonder whether integration of science and policy went too far and whether boundaries were blurred. 'Simon's office and the professional pressure groups were barely distinguishable in personnel and policy' (Lambert 1963, p. 302). The admirable humanitarian and scientific goals, as well as Simon's personal integrity and prudence may well have masked the risks inherent in this strategy of merging advocacy and research, of using knowledge as a form of soft power in the hands of the central public health administration. Yet the system largely worked well and was flexible enough to keep growing and evolving.

My point is not to idealize Farr's GRO and Simon's state medicine, but to see at work models of practical integration that, without being perfect, achieved the kind of balance that allowed knowledge and institutions to grow and to provide workable and evolving resources to cope with important social problems. Now it is time to turn to another historical example, one where promising circumstances were not sufficient to achieve the hoped for results. Poor practical integration got in the way.

\section{Post-war British Town Planning}

In this section I look at British town planning in the three decades after the war, a period that saw first the sudden rise of town planning and then its 
profound crisis. My analysis covers the period from the Second World War to the early 1970s.

\subsection{The rise}

Like public health, town planning was an answer to the major social problems stemming from massive and unregulated urbanization. But it made slower progress into public administration and public conscience. Things were moving in the late 1930s, but it was the war that provided the turning point and the springboard for planning's take off. While huge problems inherited from the Victorian age were still largely unresolved, the destructions caused by German bombing sounded a call for action and provided an opportunity for reconstruction (Grindrod, 2013, pp. 21-2, 105-110). Even more decisive was the psychological and political change effected by the war: 'The Second World War convinced the British public of the need for planning: economic planning, military planning, social planning, town and country planning' (Meller, 1997, p. 67; cf. Cherry, 1996, p. 105 and Glass, 1973, p. 50). Already during the war activity was intense: four official reports on issues related to planning and five different plans for London appeared (Meller, 1997, p. 67; Cherry, 1996, p. 101-6). Pressure groups, led by the Town and Country Planning Association, were lobbying actively and planning ideals and infrastructures made decisive inroads into public administration: in 1943 a Ministry of Town and Country Planning was set up; unprecedented powers were conferred to planning by the 1944 Town and Country Planning Act. The same year a White Paper, The Control of Land Use, envisaged the most comprehensive and ambitious vision of planning yet proposed. The remarkable momentum of town planning continued under the Labour governments in the years up to 1951. Gordon Cherry summarises very effectively the consolidation of town planning as a staple concern of local governance:

It is impossible to underestimate the importance of the period 1945-51 in the twentieth century history of town and country planning. It was in these years that the hopes of pre-war enthusiasts were met, and when a Cinderella profession was propelled into post-war reality with legislative backing and a statutory system within which to act. The period was a bridge, almost literally, in the middle of the century, between two very different experiences: previously town planning had been largely a matter for enthusiastic amateurs, a handful of consultants, and the pressure of a garden city lobby; afterwards it became institutionalized and the concern of bureaucrats and 
professionals in the corridors of local government power (Cherry, 1996, p. 131).

This 'golden age' of British planning (Batty, 1979; Meller, 1997, ch. 5; Taylor, 1998, ch. 3) was supported by a coalition including the political leadership (the coalition government during the war and the labour cabinet afterwards), the advocates of planning, civil servants, and the population willing to 'build a better Britain' after the hardships of the economic depression of the 1930s and of the war.

The profession that took advantage of these promising circumstances had recently formed the Town Planning Institute, providing itself with a governing body that determined the education criteria and acted as gatekeeper. Born out of the initiative of architects, surveyors and civil engineers ${ }^{15}$ the profession developed a rather narrow technical character. In spite of the anarchist and utopian origins of town planning, politics and broader social vision were renounced in favour of technical expertise and the naïve assumption of a spontaneous harmony with social and economic planning. According to Nigel Taylor, the profession 1) saw itself as concerned with the planning of the physical built environment, not with social, political or economic planning; 2) was performed essentially as 'an "extension" of architectural design' (Taylor, 1998, loc. 154); 3) its main point was the production of 'master' plans or detailed blueprints. The heritage of utopianism survived in the focus on the final result and disregard of the practical means: 'nowhere is found a discussion of implementation or updating' (Hall, 2002, p. 356; cf. Glass, 1973, p. 55-6).

The profession thus had become much less interdisciplinary than some of its founding fathers - e.g. Patrick Geddes-had envisaged. The post-war cultural climate contributed to foster the illusion that broad consensus and unity of intents obtained around social goals and people's needs. The goals and values of planning were thus assumed to be a matter of common sense, neither needing special social scientific knowledge nor ethical justification. Contingent sociological reasons contributed to the lack of a social scientific component in town planning. Economists had enough employment opportunities in a civil service that was rapidly expanding and was increasingly involved in managing the economy. Sociologists had disappeared from Britain in the years between the First World War and the

15 Hall (2002, p. 354); see also Cherry (1996, p. 132); Foley (1960, p. 214) who, in addition, acknowledges a minor role to lawyers, economists and geographers. 
1950s (Soffer, 1982, p. 768). Geographers got more involved, but focused on drawing maps and thus contributed to the narrow design-oriented character of the discipline (Crone, 1964, pp. 211-3).

\subsection{Crisis}

Starting from the 1950s town planning faced increasingly exacting challenges: both practical and theoretical. This was not an exclusively British phenomenon, indeed the turbulence manifested slightly earlier in the United States, and while the social and practical causes, as well as the institutional circumstances, had significant differences, the theoretical challenges were common and travelled across the Atlantic very fast. But let us look first at the social causes.

Post-war British planning had assumed a remarkably static social and economic world, with little economic and social growth, little internal migration and foreign immigration. Further it had assumed an effective state control over economic life, industrial development and redevelopment - that would have also controlled the distribution of the population so as to make it more even - and most importantly public control and funding of urban reconstruction and renewal. From the 1950s these assumptions began to fall like a row of dominoes. The baby boom brought about unexpected demographic growth and demand for more housing; the shift towards smaller households compounded the problem; the economic boom produced expectations of higher standards of living and especially an increased demand of such land-hungry goods as houses and cars; the mass diffusion of automobiles put enormous pressure on road traffic. Classes and poverty refused to disappear, together with urban decay and speculations. Moreover the unexpected flow of immigrants from the former colonies brought renewed attention to problems of urban poverty and segregation, complicated by new issues of interracial relations and racism. The sense of unity and the postwar consensus were rapidly eroding. Building and new housing were increasingly provided by private developers and hence much less amenable to planning control and public goals. Internal migration continued and the economy progressively shook off public control (See Hall, 1985; Cullingworth, 1994). The result was that the achievement of post-war goals was seriously incomplete, while planners began to feel frustrated and disappointed, ill-equipped and powerless in a fast changing and uncertain world and that the public grew disillusioned and voiced harsh criticisms - for instance through the influential voices of the architect Ian Nairn and the poet 
John Betjemann (cf. Cherry, 1974; Tewdwr-Jones, 1999). Planners' role 'changed from one where they were seldom challenged, to one that was undermined from without and within' (Ravetz, 1986, p. 121).

Other disciplines contributed to shake planners' certainties. Developments in computer science and cybernetics led to the emergence of computational models and system theory. Before long, economists applied these techniques to the study of traffic flows, and then inspired system planning that came to dominate in the 1960s and then declined. However, system planning radically changed the practice of planning and in particular laid to rest the idea that the main task of planners was to produce a blueprint of land use in the form of a master plan. Advances in management suggested that a more multidisciplinary approach was necessary to address decision-making and planning in open and complex systems. At the same time political scientists and policy analysts were stressing both the plurality of interests and values in society and inescapable frictions, negotiations and compromises that characterize the formulation and implementation of policies. Sociologists showed that urban renewal had broken communities rather than building them. All the assumptions of post-war planning were falling apart.

From the 1960 the profession experienced a profound identity crisis: planners were no longer confident in their methods, knowledge and role ${ }^{16}$. Perhaps the most dramatic - if a bit overstated - account of the profound transformation that occurred is provided by Michael Batty:

Prior to about 1960 ... planning was an expertise akin to a craft: its knowledge base was personal and its process was implicit, acquired by experience and thus highly professionalized. Its problems were easy to define and its solutions were equally easy to engender. But the increasing uncertainty and complexity manifest in society had a profound effect. The golden age of stability and certainty disappeared almost overnight. The discipline of physical planning changed more in 10 years from 1960 to 1970, than in the previous 100, possibly even 1000 years. Once the threshold from the certain, simple world of the past to the uncertain, complex world of the present was passed, the discipline experienced a change of quite revolutionary proportions which is clearly manifest in its process, its methodology (Batty, 1979, p. 18).

\footnotetext{
16 The crisis is clearly evident in the literature of the 1960s and 1970s. See for instance Glass (1973); Jacobs (1993); Davidoff (1965); Bolan (1967); Gans (1968); Pahl (1975); Rittel and Webber (1973); Friedmann \& Hudson (1974); Galloway \& Mahayni (1977). Historical accounts are also in agreement about the crisis although they point out that theoretical crisis and external criticism went together with a new wave of planning activism. See Cherry (1974 and 1996); Ravetz (1986); Taylor (1998); Hall (2002).
} 
Planners were busy trying to find scientifically valid methods for planning and socially acceptable justification for the work and practice of town planning departments. From being an activity that enjoyed broad political and popular support, planning had turned to be an activity that was scientifically and politically suspect, and subject to public vilification. The ethics and the epistemology of planning were under scrutiny and planners were nervous about the robustness of their credentials.

\subsubsection{The VIK interpretation of the crisis of planning}

At first it may seem quite obvious that town planning as it emerged in postwar Britain had solid institutional entrenchment, but serious deficiencies in its knowledge and values bases. As Ruth Glass realized already in 1959,

By virtue of becoming an established institution and an established profession respectively, both [the planning system and the profession] have acquired vested interests in maintaining themselves unchanged... .Neither the institution nor the profession has those built-in controls of scepticism which make it possible to remain young. Altogether, planning has become respectable far too easily and far too quickly (Glass, 1973, p. 52).

This remains a remarkable insight, but needs further articulation. The VKI perspective suggests a more detailed analysis, according to which post-war planning suffered from a serious failure of integration at two different levels.

1. The coalition that promoted the rise of town planning was too narrow in each of the three dimensions (values, knowledge and institutions).

2. The illusion of independence and of possessing enough regulative and executive power obscured the need to integrate with other actors and agencies. This illusion of self-sufficiency along the three dimensions of power prevented town planning from pursuing practical learning and broader coalition building. Flexibility and evolving capacity were not built.

Let me briefly expand on these points.

\subsubsection{Institutional entrenchment without integration}

While town planning became rooted in governmental administration, its integration with other administrative branches proved too weak, in particular economic and industrial planning failed to support as expected the town planning effort. Even more serious was the imperfect distribution of 
responsibilities and resources at the level of local government. It soon became clear that effective town planning in the changing circumstances that were emerging could only take place at the level of the city region, for cities kept growing at their fringes, especially beyond the green belt, and hence beyond the boundaries of the local government power. There was therefore a problem of lack of correspondence between the area that should be the subject of town planning and the local government administrative divisions. The division between cities and their hinterlands 'made effective planning of entire urban regions a virtual impossibility' (Hall, 1985, p. 158). This structural problem remained unsolved even after the 1972 Local Government Act.

In sum, the institutionalisation of planning was successful to the extent that it made town planning part and parcel of British governmental policy and local administration. But the institutionalisation of town planning was deficient in terms of creating an administrative framework that was flexible enough to adapt to change and that was well tailored to operate at the right scale to effectively govern urban transformation-'powers of implementation were lacking' (Ravetz, 1986, p. 89).

\subsubsection{Values opacity and conflict evasion}

The role of values in post-war planning is difficult to pin down. Positive values and evils to be removed were part of the rhetoric of planners: cities should be healthier, provide better housing and more amenities; overcrowding, sprawling and unregulated development needed to be avoided. These were common claims and did not meet with many objections. The problem is that relying on such platitudinous values provided an excuse for evading any serious and thorough discussion. Taking values as uncontroversial and as object of consensus became itself a normative assumption (Taylor, 1998, ch. 2), which furthered some of planners' selfserving purposes. On the one hand, as Foley (1960) points out, it allowed a sort of ideological opportunism, or 'adaptive mechanism' needed to win the support of both political sides. On the other hand, it fostered the deceptive (and self-deceived) view that planners were simply technical experts in the service of a "unitary" view of the common interest' (Taylor, 1998, loc. 471). Hence the political dimension of planning was denied. Both Foley and Taylor note that 1 ) the mission and ideals of planning were heterogeneous and not easy to reconcile; 2) there were no conscious efforts to make the goals and values of planning explicit (see also Hall, 1985, p. 280 and Cherry, 1996, p. 146). Avoiding explicit and systematic discussions of values allowed planners to evade a difficult issue, but it came at a price. First, turning a blind eye to 
conflicts of values and interests among stakeholders blocked a vital channel of information and understanding of social reality. Second, planners failed to develop the capabilities to handle conflicts of values. Using intuition and personal judgment proved quite indefensible when planning came under criticism, for it lacked transparency and justification. Avoiding any explicit and deep discussion of values prevented planners from seeing the storm approaching and to develop one key skill for dealing with it.

\subsubsection{Knowledge without learning}

This is the dimension that better exemplifies the shortcomings of planning. A common thread in the criticisms of planners that were emerging in the 1960s was the accusation that they had a poor understanding of urban realities and dynamics (Jacobs, 1993). 'What planners lacked, and what planning theory had failed to provide, was an adequate empirical understanding of the world they were seeking to manipulate' (Taylor 1998, loc. 798). Planners assumed that the knowledge needed was available, through a mixture of borrowing and synthesizing freely from other disciplines, personal expertise and observation. Survey-analysis-planning was the three-step method inspired by Geddes. It was a 'one-shot' process: continuous learning, updating and implementation were not part of planning method or practice (Hall, 2002, pp. 356-7). 'The process was assumed to be able to generate the best plan directly and the idea that the best might not be discovered in a straightforward manner, was never broached' (Batty, 1979, p. 31). But as planning results came under attack, it became clear that the level of complexity and uncertainty of the urban environment had been grossly underestimated. More knowledge was needed, but what kind of knowledge exactly was a matter for debate. More realistic goals needed to be pursued, but which goals exactly was a matter for controversy. System planning revolutionised methods and shifted attention from the end result to the process of planning. But by 1973, Douglass Lee's influential article 'Requiem for Large Scale Models' sanctioned the declining fortune of system planning. The suspicion that the task of town planning was daunting and almost superhuman was mounting. Two articles published in Policy Sciences in 1973 (by Rittel and Webber, and Wildavsky respectively) epitomize the reasons for distrusting claims to provide technical solutions to complex social problems, which Rittel and Webber memorably described as 'wicked'. Once the hope in a comprehensive understanding of the problems faced by planners was lost, a new trend emerged that saw planning as an on-going process of social learning and acknowledged that the urban, social and physical environment talked back to 
the planning process. The urban system was finally seen as neither closed nor passive. This implied a much humbler estimate of achievable goals. The experience of the post-war grand challenge of improving urban life through the transformation of its physical layout ultimately led to a radical reappraisal of what could be expected from town planning:

Planning through learning about the appropriate ways to link knowledge to action and vice versa represents the only response, a response difficult to accept for a society wedded to the concept of the definitive solution but one which is inevitable" (Batty, 1979, p. 44).

Town planning's initial naïve optimism, lack of developed theory and of adequate empirical analysis had finally found its nemesis and come full circle. The utter inadequacy of a modus operandi that ignored the need of collecting feedback, learning and adapting in the process of acting had been fully exposed. Cullingworth (1994, p. 290) significantly concluded that 'there seems little doubt that in the perpetual planning conflict between flexibility and certainty, the former is the clear winner'.

\section{Conclusion}

Conflict is the gadfly of thought. ...is a sine qua non of reflection and ingenuity.

(Dewey, 1988, p. 207)

Early sanitarians (like Chadwick) and early post-war planners showed exaggerated confidence in their broadly technical solutions. They attempted to force them on a reality in which these solutions did and could not fit. Their lack of concern for practical integration and continuous learning in action caused their failure. The next generation of public health advocates and town planners had to learn humility and the importance of practical reason and integration, of local knowledge, values and strategic judgement ${ }^{17}$. For town

\footnotetext{
${ }^{17}$ John Simon-an important inspiration for the ideas developed in this paper-explicitly articulated this wisdom. In the preface to his English Sanitary Institutions (Simon, 1890), he clarified that that work was not meant to be a contribution to medical science, but to the very important task of promoting the welfare of the people. He explained that even within the context of that task 'Medical Science is only joint-worker with other powers of knowledge and action for the national interests that are in question ... In parts of the endeavour, it can work sufficiently well by itself; but in other parts, it eagerly looks around for allies' (Simon, 1890, pp. vii-viii). In all the advances that promote better understanding, more ethical behaviour, more economic and organisational efficiency 'the medical specialist gratefully recognises types of contribution, often not less necessary than his own, towards that great system of Preventive Medicine which is hoped for by Sanitary Reformers' (p. viii). Simon understood that neither science nor politics can
} 
planners the early mistake meant missing a unique window of opportunity and earning a poor reputation that they are still struggling to overcome (see Tewdwr-Jones, 1999; Ellis \& Henderson, 2014, p. 4).

Another lesson that emerges from the case studies is the importance of limits. The notion of limits applies at various levels. Seeing practical reason as the combination of general and local knowledge, instrumental rationality, phronesis and metis implies that each component taken alone is limited and cannot work properly but in combination with the others. Similarly values, institutions and knowledge need each other to work properly - they are necessary but not sufficient conditions for the exercise of collective practical reason. There is therefore a sense in which each of the elements of practical reason and of practical integration is limited and in need of being supplemented or integrated. Their limits call for complementarity. But this also means that they limit each other: the claims of each component are limited by those of the others. An ecological balance is necessarily a reciprocal limitation.

Finally, the logic of integration itself needs to be limited: integration is not always an ideal process: I have stressed the need of trade-offs and pragmatic compromises that are unavoidable when operating in non-ideal conditions and aiming at action. Integration through reciprocal limitation requires that different demands, coming from different dimensions of the VIK triangle and from the plurality internal to each dimension, should be heeded and acknowledged even when they are not satisfied. We need to preserve a plurality of independent sources of legitimate and potentially conflicting demands, because we deal with complex and multidimensional problems. If pushed too far integration irons out necessary frictions that act as healthy checks and remainders of our shortcomings. Therefore, the demands of practical integration are pragmatically justified and do not call for epistemic rationalizations. Practical integration should not aim at obliterating ethical and epistemological conflicts: on the contrary such conflicts instruct us on the limits of our knowledge and actions.

This view of integration is based on the assumption that the multidimensionality of social problems makes them complex, shifting, openended and characterized by conflicting desiderata. They are not neat ('tame') problems with clear and ultimate technical solutions. They belong to the family of issues that have been variously described as 'wicked problems'

claim a privileged, dominant status, but that they can play either leading or supporting role depending on the task. 
(Rittel and Webber, 1973), 'messes' (Ackoff, 1981), 'adaptive' problems (Heifetz, 2001), belonging to the 'swamp' (Schön, 1987) and involving conflicting perspectives on values (Rein, 1976; Schön \& Rein, 1994) ${ }^{18}$. Hence they are issues for which 'conclusive solutions are very rare' (Head \& Alford, 2013: 2; cf. Bammer, 2012, ch. 34 and Brown et al., 2010), but that can nonetheless be handled so as to make them more tractable. Therefore in responding to Grand Challenges we should embrace humility: instead of the hubris of aiming at solutions, or techno-fixes; we should remember that these are problems that can seldom be solved, and that we should rather aim for intelligent, evolving problem-coping. We can set up networks and organisations that keep adapting as problems evolve, that keep improving our knowledge and understanding, that keep looking for responses to the needs and interests that have not yet been satisfied.

However, we should notice a constitutive tension in the attempt to set up institutions capable of linking values, knowledge and action: the tension, as it were, between reinventing the wheel and fighting the last war. When values that have been accepted by public opinion and lessons that have been learned from previous policies are ingrained in existing institutions they acquire a sort of hegemonic inertia: they inform the ethos and praxis of expert agencies. Furthermore they create learning biases, which enable us to learn some things, but conceal other issues. When circumstances change substantially and social priorities and sensibilities shift, such inertia is a hindrance and blind spots are crippling. Overcoming this inertia without losing accumulated expertise is itself a Grand Challenge worthy of attention: the challenge of integrating the skills of acting here and now while looking forward, backward and sideways.

\section{Acknowledgements}

I would like to thank the two anonymous referees: their perceptive criticisms and suggestions have been extremely useful and forced me to improve the paper in several ways. My co-editor Sophia Efstathiou has been generous in advice, constructive criticism and encouragement. Annamaria Carusi, Edmund Ramsden, Bengt Molander and Rita d'Oliveira Bouman have read previous drafts or parts thereof and given helpful feedback and encouragement.

\footnotetext{
18 The important similarities between these ideas were brought to my attention by Chapman et al. (2009, pp. 13-5).
} 


\section{References}

Ackoff, R.L. (1981). The Art and Science of Mess Management. Interfaces, 11 (1), 20-26.

Alvargonzález, D. (2011). Multidisciplinarity, Interdisciplinarity, Transdisciplinarity, and the Sciences. International Studies in the Philosophy of Science, 25 (4), 387-403. DOI: 10.1080/02698595.2011.623366

Argyris, C., Putnam, R. and McLain Smith, D. (1985). Action Science. San Francisco: Jossey Bass.

Bammer, G. (2012). Disciplining Interdisciplinarity. Integration and Implementation Sciences for Researching Complex Real-world Problems. Canberra: ANU E Press.

Batty, M. (1979). On Planning Processes, in Goodall, B. G. and Kirby, A. M. (eds.), Resources and Planning (pp. 17-45). Oxford: Pergamon Press.

Berlin, I. (1996). The Sense of Reality. Studies in Ideas and their History. London: Pimlico.

Bernardello, G. (2002). Review of Kress, W.J. \& Barrett, G.W. (eds.), 'A new century of biology'. Plant Systematics and Evolution, 234 (1), 235-237. DOI: $10.1007 / \mathrm{s} 006060200094$

Bolan, R. S. (1967). Emerging Views of Planning. Journal of the American Institute of Planners, 33 (4), 233-245. DOI: 10.1080/01944366708977924

Brister E., Disciplinary capture and epistemological obstacles to interdisciplinary research: Lessons from central African conservation disputes. Studies in History and Philosophy of Biology and Biomedical Sciences, in this issue.

Brooks, S., Leach, M., Lucas, M. and Millstone, E. (2009) Silver Bullets, Grand Challenges and the New Philanthropy. Brighton: STEPS Centre. STEPS Working Paper 24.

http://www.ids.ac.uk/files/dmfile/STEPSWorkingPaper24.pdf 
Brown, V.A., Harris, J.A. \& Russell, J.Y. (eds.) (2010). Tackling Wicked Problems through the Transdisciplinary Imagination. London and Washington DC: Earthscan.

Bynum, W.F. (1994). Science and the Practice of Medicine in the Nineteenth Century. Cambridge UK: Cambridge University Press.

Calvert, J. (2013). Systems Biology, Big Science and Grand Challenges. Biosocieties, 8, 466-479. DOI:10.1057/biosoc.2013.27

Chapman, Jake, Edwards, Charlie and Hampson, Simon, (2009), Connecting the Dots, Demos, London.

http://www.demos.co.uk/files/Connecting the dots - web-2.pdf

(last accessed 31/03/2015)

Cherry, G.E., (1974). The evolution of British town planning : a history of town planning in the United Kingdom during the 20th century and of the Royal Town Planning Institute, 1914-74. Leighton Buzzard: Leonard Hill.

Cherry, G.E., (1996). Town Planning in Britain Since 1900: The Rise and Fall of the Planning Ideal. Oxford: Blackwell.

Crone, G.R. (1964). British Geography in the Twentieth Century. The Geographical Journal, 130 (2), 197-220.

Cullen, M.J. (1975). The Statistical Movement in Early Victorian Britain: The Foundations of Empirical Social Research. Hassocks: Harvester Press.

Cullingworth, B. (1994). Fifty Years of Post-War Planning. The Town Planning Review, 65 (3), 277-303.

Davidoff, P. (1965). Advocacy and Pluralism in Planning. Journal of the American Institute of Planners, 31 (4), 331-338. DOI:10.1080/01944366508978187

Detienne, M. \& Vernant, J.-P. (1974). Les Ruses de l'Intelligence: La Metis des Grecs. Paris: Flammarion.

Defila, R. \& Di Giulio, A. (2015). Integrating Knowledge: Challenges raised by the 'Inventory of Synthesis'. Futures, 65, 123-135. DOI:

10.1016/j.futures.2014.10.013 
Dewey, J. (1988). Human Nature and Conduct. Carbondale and Edwardsville: Southern Illinois University Press. (First published 1922).

Dewey, J. (2004). Reconstruction in Philosophy. Mineola NY: Dover. (First published 1920).

Dupré J. (1996). Metaphysical disorder and scientific disunity, In: Galison P. and Stump D.J. (Eds.), The disunity of science: Boundaries, contexts, and Power, Stanford: Stanford University Press.

Dyson, F. (2007). Our biotech future. The New York Review of Books, 54 (12) (Also available at http://web.pdx.edu/ pmoeck/pdf/biotech\%20future.pdf) (Last accessed 20/09/2015)

Efstathiou S., Is it possible to give scientific solutions to Grand Challenges? On the idea of Grand Challenges for life science research. Studies in History and Philosophy of Biological and Biomedical Sciences, in this issue.

EPSRC (2014). Engineering Grand Challenges.

http://www.epsrc.ac.uk/newsevents/pubs/engineering-grand-challenges/ (Last accessed 01/04/2015)

Eyler, J.M. (1979). Victorian Social Medicine. The Ideas and Methods of William Farr. Baltimore \& London: Johns Hopkins University Press.

Flyvbjerg, B. (1993). Aristotle, Foucault and Progressive Phronesis: Outline of an Applied Ethics for Sustainable Development. In Winkler, E.R. \& Coombs, J.R. (eds.). Applied Ethics. A Reader (pp. 11-27). Oxford UK and Cambridge MA: Blackwell.

Flyvberg, B. (2001). Making Social Science Matter. Cambridge UK: Cambridge University Press.

Foley, D. (1960). British Town Planning: One Ideology or Three?

The British Journal of Sociology, 11 (3), 211-223.

Friedmann, J. \& Hudson, B. (1974). Knowledge and Action: A Guide to Planning Theory. Journal of the American Institute of Planners, 40 (1), 2-16. DOI: 10.1080/01944367408977442 
Frodeman, R., Mitcham, C. \& Sacks, A.B. (2001). Questioning Interdisciplinarity. https://www.academia.edu/2722096/Questioning interdisciplinarity (Originally published in Science, Technology, and Society Newsletter, 126-7, 1-5).

Funtowicz, S.O. and Ravetz, J.R. (1993), The Emergence of Post-normal Science. In von Schomberg, R. (ed.), Science, Politics and Morality. Scientific Uncertainty and Decision Making (pp. 85-123). Dordrecht: Springer.

Galloway, T.D. \& Mahayni, R.G., (1977). Planning Theory in Retrospect: The Process of Paradigm Change. Journal of the American Institute of Planners, 43 (1), pp. 62-71. DOI: 10.1080/01944367708977761

Gans, H.J. (1968). Plans and People. New York: Basic Books.

Gerson, E.M. (2013). Integration of Specialties: An Institutional and Organizational View. Studies in History and Philosophy of Biological and Biomedical Sciences, 44 (4), 515-524. DOI: 10.1016/j.shpsc.2012.10.002

Gibbons M., Limoges C., Nowotny H., Schwartzman S., Scott P. and Trow M. (1994). The New Production of Knowledge. The Dynamics of Science and Research in Contemporary Society. London, Thousand Oaks and New Dehli: Sage.

Glass, R. (1973). The Evaluation of Planning: Some Sociological Considerations. In Faludi, A. (ed.). A reader in Planning Theory (pp. 45-67). Oxford: Pergamon Press (First published in 1959 in International Social Science Journal).

Green, S. \& Wolkenhauer, O. (2012). Integration in Action. EMBO reports, 13 (9), 769-771.

Grindrod, J. (2013). Concretopia. A Journey around the Rebuilding of Postwar Britain. Brecon: Old Street Publishing.

Hall, P. (1985). Urban and Regional Planning. Second Edition. London: G. Allen \& Unwin.

Hall, P. (2002). Cities of Tomorrow. An Intellectual History of Urban Planning and Design in the Twentieth Century. Second Edition. Oxford: Blackwell. 
Halliday, S. (2011). The Greath Filth. Disease, Death and the Victorian City. Stroud: The History Press.

Hamlin, C. (1996). Edwin Chadwick, "Mutton Medicine" and the fever question. Bulletin of the History of Medicine, 70, 233-265.

Head, B.W. \& Alford, J. (2013). Wicked Problems: Implications for Public Policy and Management. Administration \& Society, XX(X), 1-29.

DOI:10.1177/0095399713481601

Heifetz, R.A. (2001). Leadership without Easy Answers. Cambridge MA: Harvard University Press.

Ellis, H. \& Henderson, K. (2014). Rebuilding Britain. Planning for a Better Future, Bristol: Policy Press.

Higgs, E. (1991). Diseases, febrile poisons, and statistics: the census as a medical survey. Social History of Medicine, 4 (3), 465-478.

Hirsh Hadorn, G., Pohl, C. \& Bammer, G. (2010). Solving Problems through Transdisciplinary Research. In Frodeman, R., Thompson Klein, J., and Mitcham C. (eds.). The Oxford Handbook of Interdisciplinarity (431-452). New York: Oxford University Press.

Huutoniemi, K. et al (2010). Analyzing Interdisciplinarity: Typology and Indicators. Research Policy, 39, 79-88. DOI: 10.1016/j.respol.2009.09.011

IET (2013). Six Global Grand Challenges Themes. London: Institution of Engineering and Technology. http://www.raeng.org.uk/publications/other/ggcs-report (Last accessed 01/04/2015)

Jacobs, J. (1993). The Death and Life of Great American Cities. New York: Modern Library. (First published 1961)

Jahn, T., Bergmann, M. \& Keil, F. (2012). Transdisciplinarity: Between Mainstreaming and Marginalization. Ecological Economics, 79, 1-10. 
Jones, R. (2010). Whose Goals Should Direct Goal-directed Research? Soft Machines, July $7^{\text {th }}$ 2010. http://www.softmachines.org/wordpress/?p=878 (Last accessed 01/04/2015)

Kekes, J. (2010). The Human Condition. Oxford: Clarendon Press.

Kitcher, P. (2012). Preludes to Pragmatism. Toward a Reconstruction of Philosophy. New York: Oxford University Press.

Klein, J. T. (2010). A taxonomy of interdisciplinarity. In Frodeman, R., Thompson Klein, J., and Mitcham C. (eds.). The Oxford Handbook of Interdisciplinarity (15-30). New York: Oxford University Press.

Lawrence, R.J. (2015). Advances in transdisciplinarity: Epistemologies, Methodologies and Processes. Futures, 65, 1-9. DOI:

10.1016/j.futures.2014.11.007

Lambert, R. (1963). Sir John Simon 1816-1904 and English Social Administration, London: MacGibbon \& Kee.

Leonelli, S. (2013). Integrating Data to Acquire New Knowledge: Three Modes of Integration in Plant Science. Studies in History and Philosophy of Biological and Biomedical Sciences, 44 (4), 503-514. DOI: 10.1016/j.shpsc.2013.03.020

Losos, J. B., Arnold, S. J., Bejerano, G., Brodie III, E. D., Hibbett, D., Hoekstra, H. E., ... \& Turner, T. L. (2013). Evolutionary biology for the 21st century. PLoS Biol, 11(1), e1001466.

Lund Declaration (2009). Europe Must Focus on the Grand Challenges of Our Times. Lund: Swedish EU Presidency.

http://www.vinnova.se/upload/dokument/Verksamhet/UDI/Lund Declaratio n.pdf (Last accessed 01/04/2015)

Lee, D.B. Jr. (1973). Requiem for Large-Scale Models. Journal of the American Institute of Planners, 39 (3), 163-178. DOI: 10.1080/01944367308977851

MacDonagh, O. (1977). Early Victorian Government 183-1870. London: Weidenfeld \& Nicholson. 
Meller, H. (1997). Towns, Plans and Societies in Modern Britain. Cambridge UK: Cambridge University Press.

Miller T.R., Baird T.D., Littlefield C.M., Kofinas G., Chapin F. III and Redman C.L. (2008). Epistemological Pluralism. Reorganizing Interdisciplinary Research. Ecology and Society, 13 (2), s.p..

Mitchell, C., Cordell, D. \& Fam, D. (2015). Beginning at the End: The Outcome Spaces Framework to Guide Purposive Transdisciplinary Research. Futures, 65, 86-96. DOI: 10.1016/j.futures.2014.10.007

National Research Council (2004). Facilitating Interdisciplinary Research. Washington DC: The National Academies Press.

National Research Council ( 2009). A New Biology for the 21st Century. Washington, DC: The National Academies Pres.

Novak, S.J. (1973). Professionalism and Bureaucracy: English Doctors and the Victorian Public Health Administration. Journal of Social History, 6 (4), 440-462.

Nowotny, H., Scott, P. \& Gibbon, M. (2001). Re-Thinking Science. Knowledge and the Public in an Age of Uncertainty. Cambridge UK and Maiden MA: Polity.

Nowotny, H., Scott, P., \& Gibbons, M. (2003). Introduction: 'Mode 2' revisited: The new production of knowledge. Minerva, 41(3), 179-194. DOI:

10.1023/A:1025505528250

O’Rourke, M., \& Crowley, S.J. (2013). Philosophical Intervention and Crossdisciplinary Science: The Story of the Toolbox Project. Synthese 190, 1937-1954. DOI: 10.1007/s11229-012-0175-y

O'Rourke M., Crowley S.J. and Gonnerman C., On the nature of crossdisciplinary integration: A philosophical framework, Studies in History and Philosophy of Biological and Biomedical Sciences, in this issue.

Pahl, R.E., (1975). Whose City? And Further Essays on Urban Society. Harmondsworth: Penguin.

Palsson, B. (2000). The challenges of in silico biology. Nature biotechnology,18 (11), 1147-1150. 
Pressman, J.L. \& Wildavsky, A. (1984). Implementation. Third Edition. Berkeley

- Los Angeles - London: University of California Press.

Rasmussen, N. (2014). Gene Jockeys: Life Sciences and the Rise of Biotech

Enterprise. Baltimore and London: Johns Hopkins University Press.

Ravetz, A. (1986). The Government of Space: Town Planning in Modern Society. London: Faber \& Faber.

Rein, M. (1976). Social Science and Public Policy. Harmondsworth: Penguin.

Rifkin, J. (1998). The biotech century: The coming age of genetic commerce. London: Victor Gollancz.

Rittel, H.W.J. \& Webber, M.M. (1973). Dilemmas in a General Theory of Planning. Policy Sciences, 4, 155-169.

Robinson, G. E., Banks, J. A., Padilla, D. K., Burggren, W. W., Cohen, C. S., Delwiche, C. F., ... \& Tomanek, L. (2010). Empowering 21st century biology. BioScience, 60 (11), 923-930.

Rorty, R. (1999), Philosophy and Social Hope. London: Penguin.

Rosen, G. (1993). A History of Public Health. Expanded Edition. Baltimore and London: Johns Hopkins University Press. (First published 1958)

Rosenberg, C.E. (2006). Anticipated Consequences: Historians, History and Health Policy. In Stevens, R.A., Rosenberg, C.E. \& Burns, L.R. (eds.). History and Health Policy in the United States: Putting the Past Back In (pp. 13-30). New Brunswick and London: Rutgers University Press.

Sarewitz, D. (1996). Frontiers of illusion: science, technology and the politics of progress. Philadelphia: Temple University Press.

Sarewitz, D. (2010). Against Holism. In Frodeman, R., Thompson Klein, J., and Mitcham C. (eds.). The Oxford Handbook of Interdisciplinarity (pp. 65-75). New York: Oxford University Press. 
Schön, D.A. (1987). Educating the Reflective Practitioner. San Francisco: Jossey Bass.

Schön, D.A. \& Rein, M. (1994). Frame Reflection: Towards the Resolution of Intractable Policy Controversies. New Youk: Basic Books.

Scott, J.C. (1998). Seeing like a State. How Certain Schemes to Improve the Human Condition Have Failed. New Haven and London: Yale University Press.

Simon, J. (1890). English Sanitary Institutions. London-Paris-New YorkMelbourne: Cassel \& co.

Soffer, R.N. (1982). Why do discipline fail? The Strange Case of British Sociology. The English Historical Review, 97 (385), 767-802.

Stengers, I. (2002), Sciences et Pouvoirs. La démocratie face à la technoscience, Paris: La Découverte.

Stirling, A. (2010). Keep it Complex. Nature, 468, 1029-1031.

DOI:10.1038/4681029a

Szreter, S. (2005). Health and Wealth: Studies in History and Policy. Rochester NY and Woodbridge UK: University of Rochester Press.

Taylor, N. (1998) Urban Planning Theory Since 1945. London, Thousand Oaks and New Dehli: Sage. [Kindle edition]

Tewdwr-Jones, M. (1999). Reasserting Town Planning: Challenging the Representation and Image of the Planning Profession. In Allmendinger, P. and Chapman, M. (eds.). Planning Beyond 2000 (pp. 123-149). Chichester: Wiley.

Toulmin, S. (2001). Return to Reason. Cambridge MA and London UK: Harvard University Press.

Venter, C., \& Cohen, D. (2004). The century of biology. New Perspectives Quarterly, 21 (4), 73-77.

Wagner C.S., Roessner J.D., Bobb K., Thompson Klein J., Boyack K.W., Keyton J. et al. (2011). Approaches to Understanding and Measuring Interdisciplinary 
Scientific Research (IDR): A Review of the Literature. Journal of Infometrics, 165, 14-26. DOI: 10.1016/j.joi.2010.06.004

Wake, M. H. (2008). Integrative biology: Science for the 21st century.

BioScience, 58 (4), 349-353.

Wildavsky, A. (1973). If Planning is Everything, Maybe it's Nothing. Policy Science, 4, 127-153.

Wohl, A. (1983). Endangered Lives. Public Health in Victorian Britain. London: J.M. Dent \& Sons. 